\title{
REVIEW
}

\section{Non-alcoholic steatohepatitis: an overview including treatments with herbals as alternative therapeutics}

\author{
Menaka Chanu Thounaojam, Ravirajsinh Navalsinh Jadeja, Ranjisinh Vijaysinh Devkar, \\ Ayalur Vadathala Ramachandran \\ Division of Phytotherapeutics and Metabolic Endocrinology, Department of Zoology, Faculty of Science, \\ The M. S. University of Baroda, Vadodara, India
}

Received $4^{\text {th }}$ August 2011.

Revised $25^{\text {th }}$ October 2011.

Published online $25^{\text {th }}$ October 2011.

\begin{abstract}
Summary
Non-alcoholic steatohepatitis (NASH), an under- recognized hepatic ailment with increasing prevalence, is fast emerging as the dark horse of hepatic related morbidity and mortality. Though introduced as a hepatic condition as early as 1980, detailed exploration of its causes, underlying mechanisms and therapeutics has largely remained an ignored or neglected field. Only recently, the focus of attention has gravitated towards an understanding of NASH as a pathological manifestation of significance and a search for possible therapeutic interventions. Treatment schedules as of now involve life style management and usage of anti-diabetic or anti-obesity drugs and antioxidants. In the present review, we have focused on the available treatment schedules including herbal agents, plant extracts, polyherbal formulations and isolated phytocompounds. We present here a review of the available literature on pre-clinical and clinical evaluations of herbals including our recent findings on two plant extracts which can be used in mitigating NASH. This review attempts to provide a comprehensive account of NASH and the future of therapeutics and remediation by herbal principles, an aspect of the urgent need to target this important medical condition that contributes to many cases of silent morbidity and mortality.
\end{abstract}

Key words: non-alcoholic steatohepatitis; herbal medicine; phytocompounds; polyherbal formulation

\section{INTRODUCTION}

Ludwig et al. (1980) were the first to introduce this condition in 1980 to describe a series of patients with hepatic cirrhosis similar to alcoholic cirrhosis but who did not have a history of alcohol consumption.

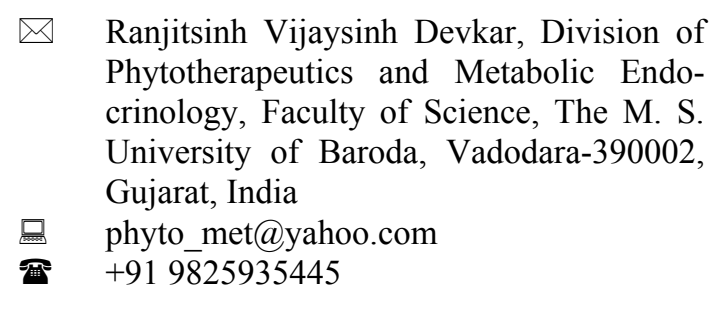

(C) Journal of Applied Biomedicine
Non-alcoholic fatty liver disease (NAFLD) is a broader category of hepatic disorder, manifesting despite non-alcoholism, and encompassing a spectrum of alterations ranging from simple fatty liver/hepatic steatosis (the accumulation of fat in liver to upward of $5-10 \%$ of the liver mass) to non-alcoholic steatohepatitis (NASH) and increasing fibrosis leading to cirrhosis, liver failure and hepatocellular carcinoma. Non-alcoholic steatohepatitis (NASH) is rapidly becoming a worldwide public health problem. Despite the high prevalence of NASH, the underlying etiological factors that determine disease progression through fibrosis to cirrhosis remain poorly understood. Moreover, the available non-invasive techniques to study hepatic metabolism in humans are limited, and liver biopsies are required to identify 
individuals with NASH (Erickson 2009). According to popula-tion-based studies on NASH, it is histologically similar to alcohol-induced steatohepatitis. Moreover, many of the factors implicated in the development of alcoholic steatohepatitis are also associated with NASH (Matteoni et al. 1999).

\section{PREVALENCE AND RISK FACTORS}

Estimates of the global prevalence among the general populace of NAFLD/NASH, a leading cause of hepatic dysfunction and cirrhosis, suggest a prevalence rate of $20-30 \%$ in the western and U.S population but with a higher incidence of $75-100 \%$ in obese $(\mathrm{BMI} \geq 30)$ and morbidly obese $(\mathrm{BMI} \geq 40)$ subjects respectively (Fan et al. 2011). In United States, NASH is the third most common liver disease after hepatitis $\mathrm{C}$ and alcoholic fatty liver (Patel and Lee 2001) with a current estimate of $20 \%$. Recent estimates suggest 6 million individuals of the general populace in U.S to have progressed to NASH and 0.6 million to NAFLD related cirrhosis (Erickson 2009). The overall prevalence of NASH in the Asia-Pacific region is at present broadly similar to that in the west (Harish and Thomas 2008). However, there are some differences between the demographic and epidemiologic features of NASH in developing and developed countries. The prevalence amongst the obese population ranges as high as $75-92 \%$ and a serious cause of concern is the prevalence of NASH even amongst the pediatric population, to the tune of about $10 \%$ in the age group 2-19 years (Manco et al. 2008). Of still greater concern, and with implications for future disease burden, is the higher rate of prevalence of NAFLD amongst obese children (Erickson 2009). Available data on national occurrence shows that NAFLD reportedly affects $20 \%$ of obese children and adolescents from the US (Strauss et al. 2000), 44\% from Italy (Sartorio et al. 2007) and 74\% from China (Chan et al. 2004). The disease associates significantly with type 2 diabetes mellitus (T2D) and all features of the metabolic syndrome (MetS) (Erickson 2009). A similar increase in the prevalence of obesity and metabolic syndrome in Asia with increasing rates of NASH suggests the likely possibility of a progressive increase in the prevalence of NASH in the next decade (Fan 2006). The most commonly identified risk factors for NASH are a high-fat diet, a high-calorific diet, a sedentary lifestyle, insulin resistance, the metabolic syndrome and its components such as obesity, hypertension, dyslipidemia and T2D (Adams et al. 2010).

\section{ETHNICITY, GENETICS AND ENVIRONMENT}

Though NASH affects all racial groups, Hispanic populations show a higher prevalence compared to White and non-White populations. Interestingly, $\mathrm{NASH}$ and cryptogenic cirrhosis are of low prevalence in African-American (AA) populations compared to White populations (Caldwell et al. 2002, Browning et al. 2004). An evaluation of hepatic triglyceride content by magnetic resonance spectroscopy by Browning et al. (2004) suggested that AA subjects are less likely to develop steatosis compared to White and Hispanic subjects. They considered the inherent biological differences in lipid metabolism [as suggested by a lesser degree of hypertriglyceridemia and a lower level of high-density lipoprotein (HDL) cholesterol] among AA subjects to be responsible for the lower incidence of steatosis in AA. In this context, genetic differences in hepatic gene expression between populations of Caucasian and AA patients with NASH have been reported (Stepanova et al. 2008). The phenotypic variation in NASH between racial and ethnic groups observed by Lewis and Mohanty (2010) lends support to the above contention. Of late, several Asian countries like Korea, China, Japan and India have witnessed an increasing incidence of NASH (Amarapurkar et al. 2007, Fan et al. 2007). New body mass index (BMI) criteria have been generated to adjust for the anthropometric difference of higher levels of visceral adiposity at a lower BMI in Asian patients with NASH compared to the Caucasian population (Fan et al. 2007).

A genetic predisposition for NASH has been suggested based on the differential prevalence of NASH among different ethnic groups and variable rates of progression in individuals with identical risk factors (Willner et al. 2001). Osterreicher and Brenner (2007) have reviewed the available literature on genetics and Edmison and McCullough (2007) have listed the identified potential genes based on the full spectrum of genes reported for NASH. The higher incidence of NASH in American populations of Hispanic origin relative to Whites and lower incidence in AA despite greater obesity provide substantiation for ethnic/racial implication in susceptibility to progressive NASH (Caldwell et al. 2002, Browning et al. 2004). The possibility of gene variants impacting shared molecular pathways between metabolic syndrome (MetS), type 2 diabetes (T2D) and cardiovascular disorder (CVD) and NASH is indicated by the higher risk for these disorders among South Asian Indian and other Asia-Pacific populations (Amarapurkar et al. 2007, Fan et al. 
2007). Similarly, NASH is of general occurrence throughout Latin America in keeping with the greater propensity for MetS in Americus-Indian populations (Lazo and Clark 2008). Although obesity and IR, identified as risk factors, can precipitate hepatic steatosis, only a minority of patients progress to NASH and cirrhosis, suggesting an apparent interplay between a genetic predisposition and environmental factors (Petta et al. 2009). Screening of NASH patients for gene variants, using genome scans, is yielding dividends as PNPLA3/adiponutrin rs 738409 $\mathrm{C} \rightarrow \mathrm{G}$ genotype, encoding for $\mathrm{I} 148 \mathrm{M}$, appears related to the severity of steatosis and fibrosis and the presence of nonalcoholic steatohepatitis (Valenti et al. 2010), and ethnic differences in this variant have been associated with differing propensities to NASH (Romeo et al. 2000). Heightened susceptibility to the development of NASH is co-relatable with polymorphisms in genes implicated in lipid metabolism, IR, oxidative stress, cytokines/ adipokines and fibrognesis (Wilfred de Alwis and Day 2007). Studies on NASH individuals have demonstrated an association between advanced hepatic fibrosis in obese patients and polymorphisms in the angiotensinogen and $T G F-\beta 1$ genes (Dixon et al. 2003).

Recently, two common SNP variants in the adiponectin gene (previously associated with cardio-metabolic risk) have been found to be associated with dietary fat in NASH patients (Musso et al. 2008). Further, Dongiovanni et al. (2010) have shown that ectoenzyme nucleotide pyrophosphate phosphodiesterase 1/ plasma cell antigen-1 (ENPP1/ PC-1) 121Gln and IRS-1 972Arg polymorphisms affecting insulin receptor activity predispose to liver damage and decrease hepatic insulin signalling in patients with NASH. Apparently, the genetic effect of defective insulin signalling may play a causal role in the progression of liver damage in NASH. Yoneda et al. (2009) have shown an association between SNPs in the angiotensin II type 1 receptor and increased risk of NASH and NASH -related fibrosis. Further studies to identify more candidate genes that may not only provide information on pathogenesis and prognosis of the disease but also serve as novel treatment targets, have been suggested (Dowman et al. 2010).

Also, screening for chromosomal regions harbouring gene variants that could influence the onset and progression of NASH in mouse models is being undertaken currently with a view to translating the information obtained to the human genome to identify areas with greater probability of NASH progression (Erickson 2009).

\section{CLINICAL FEATURES AND DIAGNOSTICS}

Many patients with NASH (30-40\%) have complained of prior non-specific symptoms like weakness, fatigue and malaise (Bacon et al. 1994). Despite the many similarities between NASH and $\mathrm{ASH}$, the former is mostly asymptomatic while the latter is symptomatic. Patients with drug induced NASH (due to nucleoside analogs, anti-mitotic agents or tetracyclines) (Diehl 1999) generally develop dramatic and rapid onset of fulminate hepatic failure. The most common symptoms of NASH patients are hepatomegaly in most of the cases and splenomegaly in some of the cases (Leevy 1962), and very often, the presence of ascites and spider angiomata indicates cirrhotic development (Itoh et al. 1987).

Despite the increased understanding of non-alcoholic fatty liver conditions, the diagnosis and staging of NASH remain to-date a difficult proposition. The only acceptable mode of diagnosis of NASH valid so far has been a consideration of medical history along with a liver biopsy. Though liver biopsy alone represents an unequivocal way of assessing the stage pf NASH, it is nevertheless beset with limitations, either over-estimating or under-estimating the degree of disease progression (Ratziu et al. 2005). Due to the many caveats associated with this technique apart from its invasiveness, reliable alternate non-invasive methods need to be pursued for effective diagnosis and staging of NASH. Though many techniques had been proposed, none have found clinical acceptance (Erickson 2009). Nevertheless, some non-invasive techniques involving a combination of radiological and laboratory techniques for staging NAFLD have found differing degrees of acceptance. A listing and description of these non-invasive techniques can be found in recent publications (Dowman et al. 2011, McPherson et al. 2010). Diagnosis of NASH usually requires testing for liver biochemistry, as most such cases stand diagnosed subsequent to an evaluation of abnormal liver function tests and/or ultrasound or computed tomography scans indicating a fatty liver status. Ultrasonography, computed tomography, magnetic resonance imaging, and radionucleotide techniques, are routine techniques employed to characterize hepatic steatosis. Ironically, none of these techniques helps distinguish between simple steatosis and steatohepatitis with progressive fibrosis. NASH being essentially a clinicohistologic entity, histology is of prime importance in confirming the diagnosis (Lewis and Mohanty 2010).

The level of aminotransferase activity seems to be typically increased by four times compared to alcoholic liver disease, with alanin transaminase 
activity being higher than aspartate transaminase. Though the bilirubin level remains in the normal range, a doubled level of alkaline phosphatase activity appears to be a feature (Charlton 2004). A detailed history of patients with abnormal liver biochemistry is necessary to exclude the possibilities of excessive alcohol consumption, steatohepatitis inducing pharmacotherapy, surgical procedures, and occupational exposure to hepatotoxins, along with a nutritional history, particularly of rapid weight gain or loss, essentially to over-rule clinical conditions associated with steatohepatitis. Some other associated clinical conditions such as Wilson's, disease, viral hepatitis, and autoimmune liver disease, whose exclusion is impossible by the simple consideration of histories require serologic/biochemical exclusion. Very often, the majority of NASH patients show one or more features of metabolic syndrome such as increased waist circumference, hypertriglyceridemia, low high-density lipoprotein cholesterol, hypertension, and a fasting glucose of $110 \mathrm{mg} / \mathrm{dl}$ or higher (Charlton 2004). It is however not clear as to how far these symptoms find specific association with NASH. A caveat however is that, aminotransferase elevations, though used to diagnose NASH, lack adequate sensitivity to detect patients with NASH and are entirely nonspecific in predicting liver injury. Though characterized by focal areas of fat in the liver, NASH can be difficult to diagnose because of difficulties in distinguishing the disease from primary malignancies or metastasis and fine needle aspiration may be required to exclude malignancy. It is also worth noting the possibility of the presence of NASH, especially the chronic progressive form, even in the backdrop of apparently normal values of liver function tests and mild fatty liver. Further complexity in the diagnosis of NASH is its non-obligatory association with obesity, MetS or T2D. Apparently, individuals free of these conditions can, and in fact, do develop NASH. Moreover, not all individuals who are obese or have MetS or T2D develop progressive NASH.

\section{ROLE OF LIVER BIOPSY}

From the above it is clear that, suspected diagnosis of NASH is essentially based on a symptomatic elevation of aminotransferases, radiological features of fatty liver and hepatomegaly while diagnostic establishment is possible in the context of clinical history. A significant feature of NASH associated hepatic triglyceride accumulation seems to be a decreased production of apolipoprotein B (Apo-B).
Increased output of reactive oxygen species (ROS) from mitochondria seems to trigger steatohepatitis and fibrosis by three main mechanisms: lipid peroxidation, cytokine induction and induction of fas ligand. A deficiency in the enzymes of peroxisomal oxidation that leads to the accumulation of significant amounts of dicarboxylic acids is apparently another major cause of micro-vesicular steatosis and steatohepatitis; an added consequence of the deficiency of peroxisomal enzymes is the sustained hyper-activation of peroxisome proliferator-activated receptor $=\alpha$ (PPAR- $\alpha$ ) regulated genes (Angulo 2002). The induction of cytokines (TNF- $\alpha$, TGF- $\beta$ and IL-8) by reactive oxygen species seems to be triggered by lipid peroxidation and the release of malon-dialdehyde (MDA) and $\mu$-hydroxy noneal (HNE). Moreover, mitochondrial ROS induced expression of fas-ligand on hepatocytes and interaction between fas-ligands of neighbouring hepatocytes may lead to fractional killing (Angulo 2002) and MDA and HNE may promote further cell death, Mallory hyaline formation and collagen synthesis.

\section{ETIOLOGY}

Currently, there exists a significant gap in our understanding of the complex etiology of NASH and its progression. No doubt it is multi-factorial and many cases appear more related to a 'Western lifestyle' (i.e. nutrient abundance coupled with a sedentary lifestyle); however, an increased risk seems more related to genetic predisposition (Erickson 2009). The first recognizable stage of NASH, "simple" benign steatosis, is an indication of an exceeded fat storage capacity of visceral adipose tissue, considered a major risk factor for NASH and its progression. Increased visceral adiposity in turn can result in a higher output of adipocyte hormones and pro- and anti-inflammatory cytokines and chemokines (Kershaw and Flier 2004), which could fan the progression of NASH to its less benign stages. Molecular pathways identified in NASH and its progression seem more similar to those activated in injured organs and tissues. The innate immune system, apart from dysregulation in lipid metabolism, also stands implicated in the initial response of the liver to insult/injury; in fact, similar mechanisms also seem related to a fibrotic response (Jou et al. 2008). Both host factors and liver specific regulators are likely to be involved in the overall development and progression of NASH. 


\section{PATHOGENESIS}

\section{First hit}

Formulation of an hypothesis on the pathogenesis of NASH occurred almost two decades after the first description of the disease in 1980; an hypothesis that was revised immediately (Day and James 1998, Day 2002) and is known as a 'two hit' hypothesis. The first hit, marked by triglyceride loading within hepatocytes known as steatosis or fatty liver (NAFLD) is due to an overflow of free fatty acids (FFA) into the liver and consequent esterification (Fig. 1). The hepatic steatosis marked by high triglyceride accumulation is reflective of an excessive inflow of FFA and this, rather than triglyceride per $s e$, seems to be the factor responsible for the first hit development of NAFLD (Shiota and Tsuchiya 2006) and the subsequent vulnerability of the liver for second hits leading to NASH and/or fibrosis (Fig. 1). As already mentioned, insulin resistance of all the causes, is the only metabolic syndrome that appears to depict a consistent association with NASH, and which can precipitate hepatic steatosis, lipolysis and hyperinsulinemia. Both lipolysis and hyperinsulinemia lead to higher FFA levels in the circulation (adipose tissue lipolysis) and in the liver (glycolytic synthesis) respectively and, the greater hepatic FFA load results in a mitochondrial oxidation overload and consequent steatosis due to decreased Apo-B production.

\section{Second hit}

This background of hepatic steatosis sets the stage of vulnerability for a second hit which, as it appears now, may represent a set of factors (multi hits) that may involve complex interactions between hepatocytes, stellate cells, adipose cells, Kupffer cells, inflammatory mediators, and reactive oxygen species driving NAFLD state to NASH (Fig. 1). Though the cause of progression from NAFLD to NASH/fibrosis remains unclear, animal studies tend to suggest that the driving force is the formation of harmful adducts as by-products of fatty acid oxidation by mitochondria, peroxisomes or microsomes. Fibrosis could be a consequence of hepatic injury inflicted by oxidized by-products (Edmison and McCullough 2007). Hepatic fibrosis is also a likely effect of increased production of hydroxynonenal (HNE) and malondialdehyde (MDA) by way of lipid peroxidation and oxidative stress, acting through stellate cells and increased production of transforming growth factor- $\beta$ (TGF- $\beta$ ) (Browning and Horton 2004). As mentioned below, an under expression of uncoupling proteins leading to increased generation of reactive oxygen species and kupffer cell activation, might aggravate injury in NASH. Additionally, leptin mediated insulin resistance could also be a factor of significance in fibrogenesis as seen from animal models of NASH (Honda et al. 2002).

\section{Involvement of inflammatory mediators}

The role of inflammatory mediators in the progression of NAFLD that could form the focus for future development of therapeutics, is also gaining attention. Two of the inflammatory proteins, adiponectin and tumor necrosis factor- $\alpha$ (TNF $\alpha)$, implicated in the pathogenesis of NAFLD seem to play pivotal roles (Fig. 1). Adiponectin, an adipose tissue hormone, when lowered, is likely to increase fatty acid oxidation and hepatic gluconeogenesis contributing to the increased severity of hepatic inflammation (Xu et al. 2003, Targher et al. 2006). TNF $\alpha$, an inflammatory cytokine elaborated by macrophages, adipocytes and hepatocytes has been reportedly elevated in obese patients with insulin resistance and NASH, which can mediate hepatic injury by the inhibition of mitochondrial electron transport, the release of ROS and the promotion of lipid peroxidation (Pessayre et al. 2004). Moreover, nuclear factor kappa beta $(\mathrm{NF}-\kappa \mathrm{B})$, a proinflammatory transcription factor is also often found elevated in patients with NASH (Lewis and Mohanty 2010). Recently, the inactivation of kupffer cells, the resident macrophages of the liver that function in both innate and adaptive immunity as active phagocytosing agents and antigen-presenting cells (via toll-like receptors, among others) to T-cells, has been found to be associated with the pathogenesis of NASH and impaired hepatic regenerative capacity. Moreover, the elimination of kupffer cells seems to improve NASH, implicating the over-activation of kupffer-cell-mediated immune response to be the underlying cause of liver injury in NAFLD. An increased hepatic lipid load seems to alter the kupffer cell physiology due to overcrowding of liver sinusoids resulting in prolonged exposure of kupffer cells to antigens, reduced kupffer cell outflow, and an attendant sustained inflammatory response. While NAFLD stands histologically defined by hepatic loading of fat, evidence also points to it being a consequence of heightened catabolic events and suboptimal hepatic defenses (Lewis and Mohanty 2010). Interestingly, patients diagnosed with both $\mathrm{NASH}$ and alcoholic liver disease also provide evidence of up regulated expression of the pro-apoptotic bax gene along with increased caspase activity, and a marker of cellular apoptosis (Ramalho et al. 2006). NASH patients also appear to reveal compromised antioxidant potential as marked by reduced glutathione levels (Vendemiale et al. 2001). 


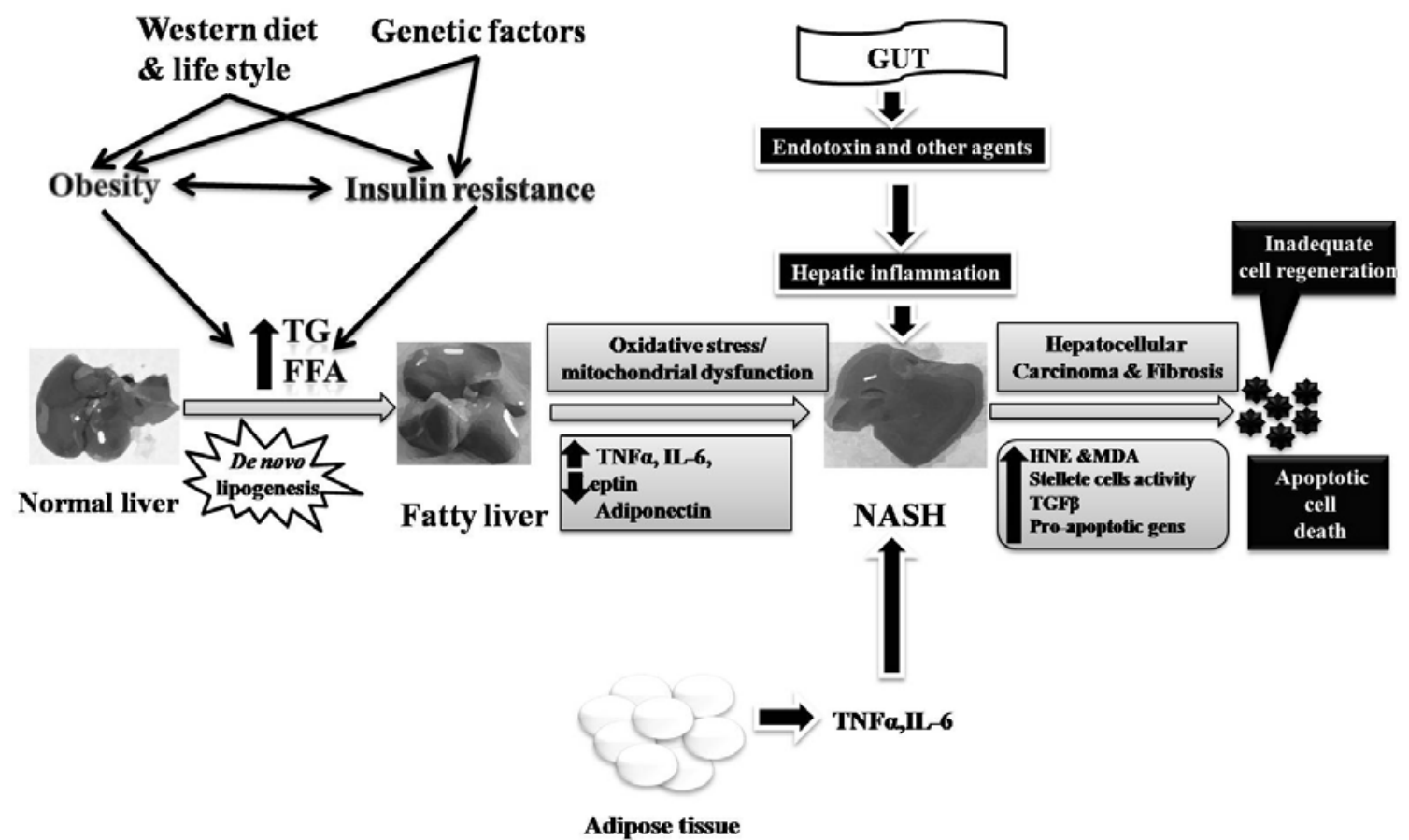

Fig. 1. Pathophysiology of nonalcoholic steatohepatitis depicting multiple hits as contributing factors.

\section{Third and multiple hit}

An additional component representing a 'third hit' was later identified reflecting inadequate hepatocyte proliferation (Jou et al. 2008). Recently, additional components representing parallel onslaughts contributing to hepatic inflammation and consequent steatosis and NASH have gained recognition. Such onslaughts or parallel hits are identified as gut-derived (endotoxin) and adipose tissue derived (tumour promoting cytokines, IL-6 and TNF $\alpha$ ) factors that promote liver inflammation and steatosis, which can then progress into NASH (Tilg and Moschen 2010). These recent inputs have given rise to the concept of 'multiple hits' contributing to the development of NASH as depicted in Fig. 1.

The earlier publication of Jou et al. (2008) clearly highlights the competence of healthy liver to undertake compensative replication of mature hepatocytes to replace dead cells and restore and reconstitute normal hepatic function. Ironically, oxidative stress implicated in NAFLD pathogenesis as a principal feature effectively inhibits the replication of mature hepatocytes and therefore goads the system instead to expansion of the hepatic progenitor cell (oval cell) population (Roskams et al. 2003). This last work highlights the capacity of these progenitor cells to differentiate into hepatocyte-like cells and draws a strong correlation between the presence of a greater number of both oval and intermediate hepatocyte-like cells with fibrosis (Roskams et al. 2003). Apparently, as suggested by the above authors, cumulative hepatocyte loss triggers the formation and accumulation of progenitor cells and their differentiation towards hepatocytes; an implicated consequence of which is hepatocellular carcinogenesis. In short, the above works reveal the compromised efficacy of hepatocyte regeneration under conditions of chronic liver injury to be the prime mover of the system towards fibrosis/cirrhosis and therefore, cell death with impaired proliferation of hepatocyte progenitors represents the proposed 'third hit' in NASH pathogenesis.

An interaction between genes and environment, that begins as early as the intrauterine period of life, is also likely to promote development of NASH. The diagnosis of the condition even in children of 3 years of age lends adequate support to this hypothesis (Manco et al. 2008). Moreover, the chances of developing NASH in children born with small gestation weight (SGA) seem much greater (Nobili et al. 2007). The concept of early life programming and developmental plasticity changes as a major conspirator for childhood or adult onset of metabolic diseases (thrifty phenotype) is well recognized and 
adequately documented in recent times (Hales and Barker 2001). The genetic-environment conspiracy concept as a major basis for the progression of metabolic diseases can also find application to $\mathrm{NASH}$, as it is usually associated with obesity, insulin resistance (IR) and all the clustering features related to metabolic syndrome (Erickson 2009). Some recent works from our laboratory have strongly demonstrated a link between early neonatal programming by corticosterone and an adult propensity for metabolic dyshomeostasis with regard to carbohydrates and lipids and a predisposition towards type 2 diabetes and/or metabolic syndrome (Baxi et al. 2011). It is likely that such individuals may be more vulnerable to a 'double' or a 'triple hit' leading to NASH and fibrosis. Apart from a predisposition towards the development of insulin resistance/metabolic syndrome during adult life, such early life experiences may also affect liver development and functioning and as such, under/malnutrition during mid and late gestational ages have been shown to maintain brain growth at the expense of trunk growth, especially growth of the liver and the establishment of liver functions (Barker 2002).

\section{TREATMENT OF NASH}

\section{Dietary and lifestyle modifications}

The first and foremost treatment for NASH is induced weight loss, along with other lifestyle modifications. It stands well documented that rapid weight loss (very low calorie diet or starvation) has a negative impact on NASH contributing to an increased risk of cirrhosis of the liver (Neuschwander-Tetri and Caldwell 2003). Therefore, instead of inducing rapid weight loss, one should aim at a controlled weight loss of less than $10 \%$ body weight over a period of 6-12 months (Okita et al. 2001). It is advisable to consume more vegetables and fruits rich in fiber and complex carbohydrates with a low glycaemic index and, avoid meat, saturated fat and products with less complex carbohydrates. Apart from lifestyle modifications, one also needs to avoid consumption of alcohol. Liver biopsy is highly recommended in patients with diabetes, dyslipidemia or glucose intolerance also diagnosed with NASH. The general diet recommendations individualized to achieve energy deficit of 500 to $1000 \mathrm{kcal}$ per day depending on the patient's BMI, involve consumption of reduced saturated fat and a total fat intake less than $30 \%$ of the total energy intake, reduced refined sugars and increased soluble fibre intake. Physical activities for
60 minutes per day for at least 3 days a week and progressive increase of an exercise regimen to five times a week form part of an ameliorative program. In the present scenario, life style modifications and dietary restrictions are the only available therapeutic approaches as no specific drugs are available to-date for treatment of NASH.

\section{Pharmacological agents}

At present, no FDA or EMEA approved drug exists against NASH, as there is no report on any agent with proven benefit. Though drugs that reduce insulin resistance such as metformin and thiazolidinediones (rosiglitazone, pioglitazone) were considered to be of some promise (Tahan et al. 2007, Sanyal et al. 2010), and some studies had shown some improvement in histological manifestations of NASH (Belfort et al. 2006), they are now being discontinued due to their adverse effects. In general, all drugs that induce weight loss might be beneficial against NASH, in particular when diet and life-style modifications do not work. Both sibutramine and orlistat have shown improvement in some characteristics of NASH such as the sonographically visible degree of liver steatosis and histologically observable degree of steatosis and fibrosis (Harrison et al. 2004, Hussein et al. 2007). Though some preliminary data tend to suggest the efficacy of metformin and glitazones in improving liver histology in patients with non-diabetic NASH, their routine use cannot be recommended at present. Some preliminary studies have also tested probiotics and various cytoprotective drugs like ursodesoxycholic acid, antioxidants like vitamin $\mathrm{E}$, anti TNF $\alpha$ agents like pentoxiphylene and antifibrotic drugs like losartan but with no success in terms of clinical application (Lirussi et al. 2007, Velayudham et al. 2009, Leuschner et al. 2010). There were also some proposals for the use of antioxidants and cytoprotective substances like vitamin $\mathrm{E}$, vitamin C, glutathione, betaine, acetylcysteine, S-adenosyl-Lmethionine and ursodesoxycholic acid in treating cases of NAFLD and NASH. However, none of these substances have shown any promise after a recent cochrane analysis of validated randomized studies (Lirussi et al. 2007).

\section{HERBAL MEDICINES AND NASH}

\section{Historical development}

Herbal medication has a traditional history stretching back to ancient times as a part of the harmonious co-existence with nature by early human civilizations. Either by a divine gift or by close observation and 
understanding of nature, ancient humans, including seers in India, had a clear perception of the availability of remedial measures in nature. Of particular importance was the development of the Indian Ayurvedic system starting from Charak Sauhita, somewhere between 400-200 B.C. The earliest literatures on Indian medicinal practice appear during the Vedic period. These, along with traditional folklore practices in other parts of the world have played a major role in the development of modern civilization. Primitive humans had great appreciation for the great diversity of plants in their immediate environment and understanding of medicinal uses of plants as medicine/curatives came not only by trial and errors methods but also by close observations of wild animals. With the passage of time more and more new herbs were added to the knowledge base of tribes and their methodological collection of information led to a well defined herbal pharmacopeia.

\section{Recent scenario}

These have essentially served as the basis for much of the modern pharmacopeia of scientific medicine. Potentially, many of the modern drugs in common use have a herbal origin and indeed at least $25 \%$ of the prescribed drugs in the world contain at least one active ingredient of herbal origin. It is of interest that about $11 \%$ of essential medicines in the list of WHO are exclusively of plant origin (Rates 2001). Primary health care of more than $80 \%$ of African and Asian populations is essentially based on traditional medicines and more than $80 \%$ of the rural population of India uses medicinal herbs as a part of the indigenous system of medicine (WHO 2008). Nearly 1000 plants species find application in Indian herbal industries, of which nearly 180 are of high volume exceeding 100 metric tonnes a year (Sahoo et al. 2010). Based on the nature of usage herbal preparations seem to fall into three categories 1) those used in the crude form as is the practice of tribal and traditional healers, 2) isolated and purified active compounds from plant extracts and 3) use after scientific validation through animal experimentation (Iwu et al. 1999). According to a WHO categorization, four groups of herbal drugs such as indigenous herbal medicine, herbal medicine in the system, modified herbal medicines and imported product with a herbal medicine base have been recognized (WHO 2003). Secondary metabolites seem to constitute the active principle chemicals of herbal preparation that affect physiological function and hence could exhibit better compatibility with the human body. The World Health Organization has recommended screening and evaluation of potential herbs for application as effective therapeutants, especially in remote areas that lack advanced health care and availability of safe modern drugs (WHO 1996). In this context, the turn of the century has witnessed an up-spring in the use of herbals in the developed world (Kamboj 2000). Though various synthetic drugs are available for the treatment of hyperlipidemia/ hypercholesterolemia and related disorders such as obesity, steatohepatitis and atherosclerosis, ironically, manifestation of side effects limit their usage to a great extent. Further, synthetic anti-diabetic and hypolipidemic drugs are also unable to alleviate the plurotropic effects of these metabolic disorders. The pharmaceutical industries therefore face a serious challenge to develop herbal alternatives or even a combination therapy against the development of NASH in diabetic, obese and IR individuals. Because of their minimal side effects and their multiple modes of action, herbal medicines are gaining increasing popularity and recognition in the management of hyperlipidemia, obesity and IR.

\section{Phytocompounds as therapeutic agents against $\mathrm{NASH}$}

Antioxidant phytocompounds are being increasingly used in combating/preventing NASH and from a literature survey, four amongst the vast array of compounds merit scrutiny for their potential against experimental NASH. Resveratrol, a type of ubiquitous polyphenol present in a variety of plants and reported to possess antioxidant and hypolipidemic (Zhu et al. 2008) potentials, has shown competence in preventing NASH in experimental models of feeding and fasting cycles (Bujanda et al. 2008). Epigallocatechin gallate (EGCG), a wellknown antioxidant phytocompound present in green tea, has demonstrated potential to ameliorate NASH in HFD fed C57BL6/J mice (Bose et al. 2008, Kuzu et al. 2008). Gallic acid and lycopene, two other popular antioxidants, have also shown ameliorative potential against $\mathrm{NASH}$; the former at a dose range of $50-100 \mathrm{mg} / \mathrm{kg}$ for 10 weeks; the latter, at a dose of $2 \mathrm{mg} / \mathrm{kg}$ for 6 weeks against HFD induced NASH in rats and NASH induced hepatocarcinogenosis (Hsu and Yen 2007, Bahcecioglu et al. 2010).

\section{Polyherbal formulations against NASH: pre-clinical and clinical studies}

Yo jyo hen shi ko (YHK), derived from Henshiko (Kyotsujigyo Inc., Japan), has four major ingredients (Panax pseudoginseng, Eucommia ulmoides, Polygonati rhizoma, and licorice root), which have found popular application against various forms of hepatic injury. De Lima et al. (2007) and Stefano et al. (2007) have shown improvement in pathophy- 
siological manifestations of NASH while, Chande et al. (2006) have successfully demonstrated the protective role of the same substance in human subjects of NASH. In another report, Lou et al. (2008) showed the therapeutic effect of Yiqi Sanju Formula (YQSJF) [traditional Chinese herbal medicine used in the treatment of non-alcoholic fatty liver disease (NAFLD)] in patients with NASH. Keishibukuryogan (KBG, TJ-25), a kempho medicine, prepared from a combination of Cinnamomum cassia, Paeonia lactiflora, Prunus persica, Poria cocos and Paeonia suffruticosa, has been shown to attenuate liver injury and inflammation in patients with nonalcoholic fatty liver disease (Fujimoto et al. 2010). Further, Fujimoto et al. (2008) have demonstrated the ameliorative effects of Orengedokuto (OGT,TJ-15), a medicinal preparation from a combination of Scutellaria baicalensis, Coptis japonica, Gardenia jasminoides, and Phellodendron amurense, as well as of Shosaikoto (SST, TJ-9), another medicinal preparation from Bupleurum falcatum, Pinellia ternata, Scutellaria baicalensis, Zizyphus jujuba, Panax ginseng, Glycyrrhiza uralensis and Zingiber officinale Roscoe against experimental NASH.

Clinical trials with plant extract/phytocompounds Compared to clinical trials on compounds/extracts of herbal origin for other diseases, there exist only a few trials for NASH. Randomized single-blind controlled clinical trials lasting for 3-4 months with extracts of grape seed and Gynostemma pentaphylum have shown potent beneficial effects in patients with NASH (Chou et al. 2006, Khoshbaten et al. 2010). Sylimarin, a flavonolignan isolated from Silybum marianum, is the most widely used hepatoprotective phytocompound against various hepatic ailments (Pradhan and Girish 2006). Studies on various preclinical models of liver disease have substantiated the hepatoprotective potential of sylimarin and, this compound alone or in combination with vitamin $\mathrm{E}$ could improve lipid profile and serum markers of hepatic function in patients with NASH (Hajaghamohammadi et al. 2008, Hajiani and Hashemi 2009, Hashemi et al. 2009). Vitamin E, a lipophilic antioxidant and vitamin $\mathrm{C}$, a hydrophilic antioxidant, have both found wide application as effective antioxidant agents against various oxidative stress related disorders and, in this context, Oliveira et al. (2003) evaluated the potential of a combination of these two in the preclinical management of NASH. The encouraging findings of this pre-clinical study led to its successful clinical trial by different research groups (Harrison et al. 2003, Vajro et al. 2004, Ersöz et al. 2005, Nobili et al. 2006). Very recently, Foster et al. (2011) have also reported the beneficial effect of a combination of Atrovastatin $(20 \mathrm{mg})$, Vitamin C $(1 \mathrm{~g})$ and Vitamin E (1000 IU) in a clinical trial.

\section{CURRENT SCENARIO AND FUTURE PERSPECTIVES}

Having witnessed the credentials of herbal preparations against various metabolic disorders, we initiated studies with two folklore plants from Manipur, India (Sida rhomboidea Roxb. and Clerodendron glandulosum Coleb) to provide scientific validity for their proclaimed efficacies (Jadeja et al. 2009). Our sequential studies demonstrated a marked potential of both these plants against a variety of conditions like hyperlipidemia and hypercholesterolemia (Thounaojam et al. 2009, Jadeja et al. 2010a), insulin resistance (Jadeja et al. 2010c, Thounaojam et al. 2010a), obesity (Jadeja et al. 2011a, Thounaojam et al. 2011a), and atherosclerosis (Jadeja et al. 2011b, Thounaojam et al. 2011b). Moreover, toxicity evaluations have also indicated relative safety for long term application (Jadeja et al. 2011c, Thounaojam et al. 2010b). Buoyed with these findings, we decided to test the possible utility of both these herbs in diet induced $\mathrm{NASH}$ in $\mathrm{C} 57 \mathrm{BL} / 6 \mathrm{~J}$ mice. Co-supplementation of high fat diet with the extracts of both plants greatly prevented the manifestations of hepatic steatosis, oxidative stress and fibrosis (Jadeja et al. 2010b; Thounaojam et al. 2010c). Substantiation for the observed effect against steatosis came from in vitro studies using HepG2 cells (Jadeja et al. 2010b, Thounaojam et al. 2010b). Recorded observations from the above studies also indicated the efficacy of the plants against conditions that predispose to NASH like hyperlipidemia, obesity and insulin resistance. Apart from our own studies, many others have also demonstrated the potential of many other plants belonging to different families on different animal models (Table 1) of NAFLD/NASH. An overview of these studies is provided in Table 2. Obviously, these encouraging results provide an impetus for more detailed studies on these plants either singly or in combination for their potential in preventing/ameliorating NASH. Such pre-clinical studies need to be taken to their logical conclusion by appropriate and controlled clinical trials.

One discordant note however regarding pre-clinical trials is the non-availability of a true mimic of human NASH as most of the animal models, genetic, dietary or stress induced seem to have one or more drawbacks (Fan and Qiao 2009, Takayama et al. 2009a). It is our considered opinion that genetic 
Thounaojam et al.: Non-alcoholic steatohepatitis and herbals

Table 1. In vivo and in vitro experimental models for non-alcoholic steatohepatitis.

\begin{tabular}{|c|c|c|c|}
\hline & Model & Mode of induction & References \\
\hline \multirow{3}{*}{ Genetic } & $\mathrm{ob} / \mathrm{ob}$ mice & $\begin{array}{l}\text { Mutation prevents synthesis } \\
\text { of leptin }\end{array}$ & Li et al. 2003 \\
\hline & $\mathrm{db} / \mathrm{db}$ mice & Mutation in leptin receptor & Larter and Yeh 2008 \\
\hline & $\mathrm{fa} / \mathrm{fa}$ mice & Mutation in leptin receptor & Larter and Yeh 2008 \\
\hline \multirow{4}{*}{ Nutritional } & C57BL/6J mice & $45-60 \%$ fat diet & Jadeja et al. 2010d \\
\hline & $\begin{array}{l}\text { Wistar and Sprague-Dawley } \\
\text { rats }\end{array}$ & $20-40 \%$ fat diet & $\begin{array}{l}\text { Shetty et al. 2010, Xu et al. } \\
2010\end{array}$ \\
\hline & Albino rats & $60 \%$ fructose rich diet & $\begin{array}{l}\text { Chidambaram and Carani } \\
\text { Venkatraman } 2010\end{array}$ \\
\hline & Albino rats & $\begin{array}{l}\text { Methionine-choline deficient } \\
\text { diet }\end{array}$ & Oz et al. 2008 \\
\hline $\begin{array}{l}\text { Nutritional + } \\
\text { physical stress }\end{array}$ & Male Wistar rats & $\begin{array}{l}\text { fat- and sugar-enriched diet } \\
\text { and chronic stress }\end{array}$ & Fu et al. 2010 \\
\hline \multirow{4}{*}{ Genetic + nutritional } & $\mathrm{ob} / \mathrm{ob}$ mice $+\mathrm{MCD}$ & $\begin{array}{l}\text { Mutation prevents synthesis } \\
\text { of leptin + MCD }\end{array}$ & de Oliveira et al. 2008 \\
\hline & $\mathrm{db} / \mathrm{db}$ mice $+\mathrm{MCD}$ & $\begin{array}{l}\text { Mutation in leptin receptor }+ \\
\text { MCD }\end{array}$ & Rinella et al. 2008 \\
\hline & $\mathrm{ob} / \mathrm{ob}$ mice $+\mathrm{MCD}+\mathrm{HFD}$ & $\begin{array}{l}\text { Mutation prevents synthesis } \\
\text { of leptin + hugh calorie }+ \\
\text { MCD }\end{array}$ & de Oliveira et al. 2008 \\
\hline & $\mathrm{fa} /$ fa rats $+\mathrm{HFD}$ & $\begin{array}{l}\text { Mutation in leptin receptor }+ \\
\text { high calorie }\end{array}$ & Carmiel-Haggai et al. 2005 \\
\hline \multirow{6}{*}{ Cell line } & \multirow{6}{*}{ HepG2 } & $\begin{array}{l}\text { Combination of palmitic acid } \\
\text { and oleic acid for } 24 \mathrm{hr}\end{array}$ & Yao et al. 2011 \\
\hline & & $0.5 \mathrm{mM}$ oleic acid for $48 \mathrm{hr}$ & Cui et al. 2010 \\
\hline & & $\begin{array}{l}0.5 \mathrm{~mm} \text { Na-palmitate-BSA } \\
\text { complex for } 24 \mathrm{hr}\end{array}$ & Wang et al. 2009 \\
\hline & & $2 \mathrm{mM}$ oleic acid for $24 \mathrm{hr}$ & Thounaojam et al. $2010 \mathrm{~d}$ \\
\hline & & $\begin{array}{l}0.7 \mathrm{mM} \text { palmitate, oleate or } \\
\text { linoleate-BSA complex for } \\
24 \mathrm{hr}\end{array}$ & Li et al. 2007 \\
\hline & & $\begin{array}{l}0.1 \% \mathrm{v} / \mathrm{v} \text { (oleic acid, linoleic } \\
\text { acid, and } \alpha \text {-linolenic acid) or } \\
0.1 \% \mathrm{w} / \mathrm{v} \text { (stearic acid)-BSA } \\
\text { complex for } 24 \mathrm{hr}\end{array}$ & Kohjima et al. 2009 \\
\hline
\end{tabular}


Table 2. Herbal extract used for treatment of NASH.

\begin{tabular}{|c|c|c|c|}
\hline Plan extract & Fraction & Experimental model & References \\
\hline Acanthopanax senticosus & $50 \%$ ethanol & HFD fed C57BL/6J mice & Park et al. 2006 \\
\hline Alisma orientalis & Methanolic & rats fed with HFD & Hong et al. 2006 \\
\hline Avena sativa $\mathrm{L}$. & Ethanol & oleic acid treated HepG2 cells & Cai et al. 2011 \\
\hline \multirow{4}{*}{ Camellia sinensis } & Theaflavins & rats fed the HFD & Lin et al. 2007 \\
\hline & Powder & $o b / o b$ mice & Park et al. 2011 \\
\hline & Fermented tea & rats fed with MCD & Mori et al. 2009 \\
\hline & Powder & $o b / o b$ mice & Bruno et al. 2008 \\
\hline Cissus quadrangularis & Methanol & rats fed with HFD & $\begin{array}{l}\text { Chidambaram and Carani } \\
\text { Venkatraman } 2010\end{array}$ \\
\hline Clerodenron glandulosum & Aqueous & C57BL/6J mice fed with HFD & Jadeja et al. 2010 \\
\hline Eriobotrya japonica & $70 \%$ ethanol & rats fed with MCD & Yoshioka et al. 2010 \\
\hline Linum usitatissimum & Seed Oil & hamster fed with HFD & Yang et al. 2009 \\
\hline Nelumbo nucifera Leaf & Flavonoids & hamsters fed with HFD & Lin et al. 2009 \\
\hline Olea europaea & Ethanol & SHR/NDmcr-cp rats & Omagari et al. 2010 \\
\hline $\begin{array}{l}\text { Origanum majorana and } \\
\text { Cichorium intybus }\end{array}$ & Aqueous & rats fed with HFD & Ahmed et al. 2009 \\
\hline Phyllanthus urinaria & Powder & $\begin{array}{l}\mathrm{C} 57 \mathrm{BL} / 6 \text { and } \mathrm{db} / \mathrm{db} \text { mice fed } \\
\text { with MCD }\end{array}$ & Shen et al. 2008 \\
\hline Picrorhiza kurroa Royle & Hydro-ethanol & Rats fed with HFD & Shetty et al. 2010 \\
\hline Platycodon grandiflorum & Saponins & C57BL/6 mice fed with HFD & Noh et al. 2010 \\
\hline Punica granatum $\mathrm{L}$. & Methanol & Zucker diabetic fatty rats & Xu et al. 2009 \\
\hline Salacia oblonga root & Water extract & Zucker diabetic fatty rats & Huang et al. 2006 \\
\hline Sida rhomboidea Roxb. & Aqueous & C57BL/6J mice fed with HFD & Thounaojam et al. 2010c \\
\hline Silibum marianum & Silibinin & Rats fed with HFD & Haddad et al. 2011 \\
\hline Teucrium polium & Ethyl acetate & Rats fed with MCD & $\begin{array}{l}\text { Amini et al. 2009, 2010, } \\
\text { Nosrati et al. } 2010\end{array}$ \\
\hline Trigonella foenum & Powder & Zucker obese rats & Raju and Bird 2006 \\
\hline Vitis coignetiae & Water extract & Rats fed with MCD & Takayama et al. 2009b \\
\hline
\end{tabular}

HFD; high fat diet and MCD; methionine choline deficient diet 
and stress induced models do not truly represent the modes of development of NASH in humans as the major causative factors are life style alterations and fat rich diet that push individuals with metabolic syndrome towards NASH. So, an appropriate strain of animals like mice, as they are genetically more alike to humans than rats, with dietary induction would be more appropriate and in this context, $\mathrm{C} 57 \mathrm{BL} / 6 \mathrm{~J}$ mice is a relevant model for a metabolic syndrome, which can proceed towards NASH with a fat rich diet.

We expect this review to generate more interest and studies on NASH, as this silent fast developing debilitating disorder needs serious and immediate attention, especially in the context of modern life style.

\section{ACKNOWLEDGEMENT}

Authors Menaka Chanu Thounaojam and Ravirajsinh Navalsinh Jadeja are thankful to the University Grants Commission and Council of scientific and Industrial Research, New Delhi India for providing financial assistance in the form of RFSMS and CSIR-SRF fellowships respectively.

\section{REFERENCES}

Adams LA, Feldstein AE. Nonalcoholic steatohepatitis: risk factors and diagnosis: metabolic risk factors for NASH. Expert Rev Gastroenterol Hepatol. 4: 623-635, 2010.

Ahmed LA, Ramadan RS, Mohamed RA. Biochemical and histopathological studies on the water extracts of marjoram and chicory herbs and their mixture in obese rats. Pak J Nutr. 8: 1581-1587, 2009.

Amarapurkar DN, Hashimoto E, Lesmana LA, Sollano JD, Chen P, Goh KL. How common is non-alcoholic fatty liver disease in the Asia-Pacific region, and are there local differences? J Gastroenterol Hepatol. 22: 788-793, 2007.

Amini R, Nosrati N, Yazdanparast R, Molaei M. Teucrium polium in prevention of steatohepatitis in rats. Liver Int. 29: 1216-1221, 2009.

Amini R, Yazdanparast R, Aghazadeh S, Ghaffari SH. Teucrium polium reversed the MCD diet-induced liver injury in rats. Hum Exp Toxicol. 30: 1303-1312, 2011.

Angulo P. Nonalcoholic fatty liver disease. N Engl J Med. 346: 1221-1231, 2002.
Bacon BR, Farahvash MJ, Janney CG, Neuschwander-Tetri BA. Nonalcoholic steatohepatitis: an expanded clinical entity. Gastroenterology. 107: 1103-1109, 1994.

Bahcecioglu IH, Kuzu N, Metin K, Ozercan IH, Ustündag B, Sahin K, Kucuk O. Lycopene prevents development of steatohepatitis in experimental nonalcoholic steatohepatitis model induced by high-fat diet. Vet Med Int. 2010. Doi: 10.4061/2010/262179, 2010.

Barker DJ. Fetal programming of coronary heart disease. Trends Endocrinol Metab. 13: 364- 368, 2002.

Baxi DB, Singh PK, Vachhrajani KD, Ramachandran AV. Diabetic glucose dyshomeostasis and dyslipidemia in estrogen deficient rats: melatonin Supplementation more potent than estrogen replacement therapy in alleviating the symptoms. Diabetol Croat. 40: 1-13, 2011.

Belfort R, Harrison SA, Brown K, Darland C, Finch J, Hardies J, Balas B, Gastaldelli A, Tio F, Pulcini $\mathrm{J}$, Berria R, Ma JZ et al. A placebo-controlled trial of pioglitazone in subjects with nonalcoholic steatohepatitis. N Engl J Med. 355: 2297-2307, 2006.

Bose M, Lambert JD, Ju J, Reuhl KR, Shapses SA, Yang CS. The major green tea polyphenol, (-)-epigallocatechin-3-gallate, inhibits obesity, metabolic syndrome, and fatty liver disease in high-fat-fed mice. J Nutr. 138: 1677-1683, 2008.

Browning JD, Horton JD. Molecular mediators of hepatic steatosis and liver injury. J Clin Invest. 114: 147-152, 2004.

Browning JD, Szczepaniak LS, Dobbins R, Nuremberg P, Horton JD, Cohen JC, Grundy SM, Hobbs HH. Prevalence of hepatic steatosis in an urban population in the United States: impact of ethnicity. Hepatology. 40: 1387-1395, 2004.

Bruno RS, Dugan CE, Smyth JA, DiNatale DA, Koo SI. Green tea extract protects leptin-deficient, spontaneously obese mice from hepatic steatosis and injury. J Nutr. 138: 323-331, 2008.

Bujanda L, Hijona E, Larzabal M, Beraza M, Aldazabal P, García-Urkia N, Sarasqueta C, Cosme A, Irastorza B, González A, Arenas JI, Jr. Resveratrol inhibits nonalcoholic fatty liver disease in rats. BMC Gastroenterol. 8: 40, 2008.

Cai S, Huang C, Ji B, Zhou F, Wise ML, Zhang D, Yang $\mathrm{P}$. In vitro antioxidant activity and inhibitory effect, on oleic acid-induced hepatic steatosis, of fractions and subfractions from oat (Avena sativa L.) ethanol extract. Food Chem. 124: 900-905, 2011.

Caldwell SH, Harris DM, Patrie JT, Hespenheide EE. Is NASH underdiagnosed among African 
Americans? Am J Gastroenterol. 97: 1496-1500, 2002.

Carmiel-Haggai M, Cederbaum AI, Nieto N. A high-fat diet leads to the progression of non-alcoholic fatty liver disease in obese rats. FASEB J. 19:136-138, 2005.

Chan DF, Li AM, Chu WC, Chan MH, Wong EM, Liu EK, Chan IH, Yin J, Lam CW, Fok TF, Nelson EA. Hepatic steatosis in obese Chinese children. Int J Obes Relat Metab Disord. 28: 1257-1263, 2004.

Chande N, Laidlaw M, Adams P, Marotta P. Yo Jyo Hen Shi Ko (YHK) improves transaminases in nonalcoholic steatohepatitis (NASH): a randomized pilot study. Dig Dis Sci. 51: 1183-1189, 2006.

Charlton M. Nonalcoholic fatty liver disease: a review of current understanding and future impact. Clin Gastroenterol Hepatol. 2: 1048-1058, 2004.

Chidambaram J, Carani Venkatraman A. Cissus quadrangularis stem alleviates insulin resistance, oxidative injury and fatty liver disease in rats fed high fat plus fructose diet. Food Chem Toxicol. 48: 2021-2029, 2010.

Chou SC, Chen KW, Hwang JS, Lu WT, Chu YY, Lin JD, Chang HJ, See LC. The add-on effects of Gynostemma pentaphyllum on nonalcoholic fatty liver disease. Altern Ther Health Med. 12: 34-39, 2006.

Cui W, Chen SL, Hu KQ. Quantification and mechanisms of oleic acid-induced steatosis in HepG2 cells. Am J Transl Res. 2: 95-104, 2010.

Day CP, James OF. Steatohepatitis: a tale of two "hits"? Gastroenterology. 114: 842-845, 1998.

Day CP. Non-alcoholic steatohepatitis (NASH): where are we now and where are we going? Gut. 50: 585-588, 2002.

de Lima VM, de Oliveira CP, Sawada LY, Barbeiro HV, de Mello ES, Soriano FG, Alves VA, Caldwell SH, Carrilho FJ. Yo jyo hen shi ko, a novel Chinese herbal, prevents nonalcoholic steatohepatitis in $o b / o b$ mice fed a high fat or methionine-choline-deficient diet. Liver Int. 27: 227-234, 2007.

de Oliveira CPMS, de Lima VMR, Simplicio FI, Soriano FG, de Mello ES, de Souza HP, Alves VAF, Laurindo FRM, Carrilho FJ, de Oliveira MG. Prevention and reversion of nonalcoholic steatohepatitis in $O B / O B$ mice by S-nitroso$\mathrm{N}$-acetylcysteine treatment. J Am Coll Nutr. 27: 299-305, 2008.

Diehl AM. Nonalcoholic steatosis. Sem Liv Dis. 19: 221-229, 1999.
Dixon JB, Bhathal PS, Jonsson JR, Dixon AF, Powell EE, O'Brien PE. Pro-fibrotic polymorphisms predictive of advanced liver fibrosis in the severely obese. J Hepatol. 39: 967-971, 2003.

Dongiovanni P, Valenti L, Rametta R, Daly AK, Nobili V, Mozzi E, Leathart JB, Pietrobattista A, Burt AD, Maggioni M, Fracanzani AL, Lattuada $\mathrm{E}$ et al. Genetic variants regulating insulin receptor signalling are associated with the severity of liver damage in patients with non-alcoholic fatty liver disease. Gut. 59: 267-273, 2010.

Dowman JK, Tomlinson JW, Newsome PN. Pathogenesis of non-alcoholic fatty liver disease. QJM. 103: 71-83, 2010.

Dowman JK, Tomlinson JW, Newsome PN. Systematic review: the diagnosis and staging of non-alcoholic fatty liver disease and non-alcoholic steatohepatitis. Aliment Pharmacol Ther. 33: 525-540, 2011.

Edmison J, McCullough AJ. Pathogenesis of non-alcoholic steatohepatitis: human data. Clin Liver Dis. 11: 75-104, 2007.

Erickson SK. Nonalcoholic fatty liver disease (NAFLD). J Lipid Res. 50: S412-S416, 2009.

Ersöz G, Günşar F, Karasu Z, Akay S, Batur Y, Akarca US. Management of fatty liver disease with vitamin $\mathrm{E}$ and $\mathrm{C}$ compared to ursodeoxycholic acid treatment. Turk J Gastroenterol. 16: 124-128, 2005.

Fan J. What are the risk factors and settings for NAFLD in Asia Pacific? The Consensus on NAFLD/NASH. APDW, Cebu 2006.

Fan JG, Qiao L. Commonly used animal models of non-alcoholic steatohepatitis. Hepatobiliary Pancreat Dis Int. 8: 233-240, 2009.

Fan JG, Saibara T, Chitturi S, Sung JJY, Kim BI, Chutaputti A. The Asia-Pacific working party for NAFLD. What are the risk factors and settings for non-alcoholic fatty liver disease in Asia-Pacific? J Gastroenterol Hepatol. 22: 794-800, 2007.

Fan JG, Jia J, Li YM, Wang BY, Lu LG, Shi JP, Chan LY. Guidelines for the diagnosis and management of nonalcoholic fatty liver disease: Update 2010. J Dig Dis. 12: 38-44, 2011.

Foster T, Budoff MJ, Saab S, Ahmadi N, Gordon C, Guerci AD. Atorvastatin and antioxidants for the treatment of nonalcoholic fatty liver disease: the St Francis Heart Study randomized clinical trial. Am J Gastroenterol. 106: 71-77, 2011.

Fu JH, Sun HS, Wang Y, Zheng WQ, Shi ZY, Wang QJ. The effects of a fat- and sugar-enriched diet and chronic stress on nonalcoholic fatty liver disease in male Wistar rats. Dig Dis Sci. 55: 2227-2236, 2010. 
Fujimoto M, Tsuneyama K, Kainuma M, Sekiya N, Goto H, Takano Y, Terasawa K, Selmi C, Gershwin ME, Shimada Y. Evidence-based efficacy of Kampo formulas in a model of non alcoholic fatty liver. Exp Biol Med. 233: 328-337, 2008.

Fujimoto M, Tsuneyama K, Kinoshita H, Goto H, Takano Y, Selmi C, Keen CL, Gershwin ME, Shimada Y. The traditional Japanese formula keishibukuryogan reduces liver injury and inflammation in patients with nonalcoholic fatty liver disease. Ann N Y Acad Sci. 1190: 151-158, 2010.

Haddad Y, Vallerand D, Brault A, Pierre S. Antioxidant and hepatoprotective effects of silibinin in a rat model of nonalcoholic steatohepatitis. eCAM. Doi: 10.1093/ecam/nep164, 2011.

Hajaghamohammadi AA, Ziaee A, Rafiei R. The efficacy of silymarin in decreasing transaminase activities in non-alcoholic fatty liver disease: A randomized controlled clinical trial. Hepat Mon. 8: 191-195, 2008.

Hajiani E, Hashemi SJ. Comparison of therapeutic effects of silymarin and vitamin $\mathrm{E}$ in nonalcoholic fatty liver disease: results of an open-labele, prospective, randomized study. Jundishapur J Nat Pharm Prod. 40: 8-14, 2009.

Hales CN, Barker DJ. The thrifty phenotype hypothesis. Br Med Bull. 60: 5-20, 2001.

Harish K, Thomas V. Non-alcoholic fatty liver disease in Asians - An emerging problem. Calcutta Med J. 6: e6, 2008.

Harrison SA, Torgerson S, Hayashi P, Ward J, Schenker S. Vitamin E and vitamin C treatment improves fibrosis in patients with nonalcoholic steatohepatitis. Am J Gastroenterol. 98: 2485-2490, 2003.

Harrison SA, Fincke C, Helinski D, Torgerson S, Hayashi P. A pilot study of orlistat treatment in obese, nonalcoholic steatohepatitis patients. Aliment Pharmacol Ther. 20: 623-628, 2004.

Hashemi SJ, Hajiani E, Sardabi EH. A placebo-controlled trial of silymarin in patients with nonalcoholic fatty liver disease. Hepatitis Monthly. 9: 265-270, 2009.

Honda H, Ikejima K, Hirose M, Yoshikawa M, Lang T, Enomoto N, Kitamura T, Takei Y, Sato N. Leptin is required for fibrogenic responses induced by thioacetamide in the murine liver. Hepatology. 36: 12-21, 2002.

Hong X, Tang H, Wu L, Li L. Protective effects of the Alisma orientalis extract on the experimental nonalcoholic fatty liver disease. J Pharm Pharmacol. 58: 1391-1398, 2006.
Hsu CL, Yen GC. Effect of gallic acid on high fat diet-induced dyslipidaemia, hepatosteatosis and oxidative stress in rats. Br J Nutr. 98: 727-735, 2007.

Huang TH, Peng G, Li GQ, Yamahara J, Roufogalis BD, Li Y. Salacia oblonga root improves postprandial hyperlipidemia and hepatic steatosis in Zucker diabetic fatty rats: Activation of PPAR- $\alpha$. Toxicol Appl Pharmacol. 210: 225-235, 2006.

Hussein O, Grosovski M, Schlesinger S, Szvalb S, Assy N. Orlistat reverse fatty infiltration and improves hepatic fibrosis in obese patients with nonalcoholic steatohepatitis (NASH). Dig Dis Sci. 52: 2512-2519, 2007.

Itoh S, Yougel T, Kawagoe K. Comparison between alcoholic and nonalcoholic hepatitis. Am J Gastroenterol. 82: 650, 1987.

Iwu MM, Duncan AR, Okunji CO. New antimicrobials of plant origin. In: Janick J, editor. Perspectives on New Crops and New Uses. ASHS Press, Alexandria 1999, p. 457.

Jadeja RN, Thounaojam MC, Ansarullah, Devkar $\mathrm{RV}$, Ramachandran AV. A preliminary study on hypolipidemic effect of aqueous leaf extract of Clerodendron glandulosum Coleb. Int J Green Pharm. 3: 285-289, 2009.

Jadeja RN, Thounaojam MC, Ansarullah, Devkar RV, Ramchandran AV. Clerodendron glandulosum Coleb., Verbenaceae, ameliorates high fat diet-induced alteration in lipid and cholesterol metabolism in rats. Rev Bras Farmacogn. 20: 117-123, 2010a.

Jadeja RN, Thounaojam MC, Ansarullah, Patel VB, Devkar RV, Ramachandran AV Protective effect of Clerodendron glandulosum extract against experimentally induced metabolic syndrome in rats. Pharm Biol. 48: 1312-1319, 2010 b.

Jadeja RN, Thounaojam MC, Dandekar DS, Devkar RV, Ramachandran AV. Clerodendron glandulosum Coleb. extract ameliorates high fat diet/fatty acid induced lipotoxicity in experimental models of non alcoholic steatohepatitis. Food Chem Toxicol. 48: 3424-3431, 2010c.

Jadeja RN, Thounaojam MC, Devkar RV, Ramachandran AV. Clerodendron glandulosum Coleb. extract prevents in vitro human LDL oxidation and oxidized LDL induced apoptosis in human monocyte derived macrophages. Food Chem Toxicol. 49: 1195-1202, 2011 a.

Jadeja RN, Thounaojam MC, Ramani UV, Devkar RV, Ramachandran AV. Anti-obesity potential of Clerodendron glandulosum Coleb. leaf aqueous extract. J Ethnopharmacol. 135: 338-343, 2011 b. 
Jadeja RN, Thounaojam MC, Ansarullah, Jadav SV, Patel MD, Patel DK, Salunke SP, Padate GS, Devkar RV, Ramachandran AV. Toxicological evaluation and hepatoprotective potential of Clerodendron glandulosum Coleb. leaf extract. Hum Exp Toxicol. 30: 63-70, 2011c.

Jou J, Choi SS, Diehl AM. Mechanisms of disease progression in nonalcoholic fatty liver disease. Semin Liver Dis. 28: 370-379, 2008.

Kamboj VP. Herbal medicine. Curr Sci. 78: 1, 2000.

Kershaw EE, Flier JS. Adipose tissue as an endocrine organ. J Clin Endocrinol Metab. 89: 2548-2556, 2004.

Khoshbaten M, Aliasgarzadeh A, Masnadi K, Farhang S, Tarzamani MK, Babaei H, Kiani J, Zaare M, Najafipoor F. Grape seed extract to improve liver function in patients with nonalcoholic fatty liver change. Saudi J Gastroenterol. 16: 194-197, 2010.

Kohjima M, Enjoji M, Higuchi N, Kato M, Kotoh K, Nakashima M, Nakamuta M. The effects of unsaturated fatty acids on lipid metabolism in HepG2 cells. In Vitro Cell Dev Biol Anim. 45: 6-9, 2009.

Kuzu N, Bahcecioglu IH, Dagli AF, Ozercan IH, Ustündag B, Sahin K. Epigallocatechin gallate attenuates experimental non-alcoholic steatohepatitis induced by high fat diet. J Gastroenterol Hepatol. 23: e465-470, 2008.

Larter CZ, Yeh MM. Animal models of NASH: getting both pathology and metabolic context right. J Gastroenterol Hepatol. 23: 1635-1648, 2008.

Lazo M, Clark JM. The epidemiology of nonalcoholic fatty liver disease: a global perspective. Semin. Liver Dis. 28: 339-350, 2008.

Leevy CM. Fatty liver: A study of 270 patients with biopsy proven fatty liver and a review of the literature. Medicine. 41: 249, 1962.

Leuschner UF, Lindenthal B, Herrmann G, Arnold JC, Rössle M, Cordes HJ, Zeuzem S, Hein J, Berg $\mathrm{T}$ et al. High-dose ursodeoxycholic acid therapy for nonalcoholic steatohepatitis: a double-blind, randomized, placebo-controlled trial. Hepatology. 52: 472-479, 2010.

Lewis JR, Mohanty SR. Nonalcoholic fatty liver disease: a review and update. Dig Dis Sci. 55: 560-578, 2010.

Li Z, Yang S, Lin H, Huang J, Watkins PA, Moser AB, Desimone C, Song XY, Diehl AM. Probiotics and antibodies to TNF inhibit inflammatory activity and improve nonalcoholic fatty liver disease. Hepatology. 37: 343-350, 2003.

Li Z, Srivastava S, Yang X, Mittal S, Norton P, Resau J, Haab B, Chan C. A hierarchical approach employing metabolic and gene expression profiles to identify the pathways that confer cytotoxicity in HepG2 cells. BMC Syst Biol. 11: 1-21, 2007.

Lin CL, Huang HC, Lin JK. Theaflavins attenuate hepatic lipid accumulation through activating AMPK in human HepG2 cells. J Lipid Res. 48: 2334-2343, 2007.

Lin MC, Kao SH, Chung PJ, Chan KC, Yang MY, Wang CJ. Improvement for high fat diet-induced hepatic injuries and oxidative stress by flavonoid-enriched extract from Nelumbo nucifera leaf. J Agric Food Chem. 57: 5925-5932, 2009.

Lirussi F, Azzalini L, Orando S, Orlando R, Angelico F. Antioxidant supplements for non-alcoholic fatty liver disease and/or steatohepatitis. Cochrane Database Syst Rev. 24: CD004996, 2007.

Lou SY, Liu Y, Ma YY, Chen HY, Chen WH, Ying J, He YM, Wang WJ. Effects of Yiqi Sanju Formula on non-alcoholic fatty liver disease: a randomized controlled trial. Zhong Xi Yi Jie He Xue Bao. 6: 793-798, 2008.

Ludwig J, TR Viggiano, DB McGill, BJ OH. Nonalcoholic steatohepatitis: Mayo Clinic experiences with a hitherto unnamed disease. Mayo Clin Proc. 55: 434-438, 1980.

Manco M, Marcellini M, DeVito R, Comparcola D, Sartorelli MR, Nobili V. Metabolic syndrome and liver histology in paediatric nonalcoholic steatohepatitis. Int J Obes. 32: 381-387, 2008.

Matteoni CA, Younossi ZM, Gramlich T, Boparai N, Liu YC, McCullough AJ. Nonalcoholic fatty liver disease: a spectrum of clinical and pathological severity. Gastroenterol. 116: 1413-1419, 1999.

McPherson S, Stewart SF, Henderson E, Burt AD, Day CP. Simple non-invasive fibrosis scoring systems can reliably exclude advanced fibrosis in patients with non-alcoholic fatty liver disease. Gut. 59: 1265-1269, 2010.

Mori A, Takayama F, Kawasaki H, Nakamoto K, Mankura M, Ogino T, Egashira T, Hidaka Y. Beneficial effects of fermented green tea extract in a rat model of non-alcoholic steatohepatitis. J Clin Biochem Nutr. 44: 239-246, 2009.

Musso G, Gambino R, De Michieli F, Durazzo M, Pagano G, Cassader M. Adiponectin gene polymorphisms modulate acute adiponectin response to dietary fat: possible pathogenetic role in NASH. Hepatology. 47: 1167-1177, 2008.

Neuschwander-Tetri BA, Caldwell SH. Nonalcoholic steatohepatitis: summary of an AASLD Single Topic Conference. Hepatology. 37: 1202-1219, 2003.

Nobili V, Manco M, Devito R, Ciampalini P, Piemonte F, Marcellini M. Effect of vitamin E on 
aminotransferase levels and insulin resistance in children with non-alcoholic fatty liver disease. Aliment Pharmacol Ther. 24: 1553-1561, 2006.

Nobili V, Marcellini M, Marchesini G, Vanni E, Manco M, Villani A, Bugianesi E: Intrauterine growth retardation, insulin resistance, and nonalcoholic fatty liver disease in children. Diabetes Care. 30: 2638-2640, 2007.

Noh JR, Kim YH, Gang GT, Yang KJ, Kim SK, Ryu SY, Kim YS, Lee CH, Lee HS. Preventative effects of Platycodon grandiflorum treatment on hepatic steatosis in high fat diet-fed C57BL/6 mice. Biol Pharm Bull. 33: 450-454, 2010.

Nosrati N, Aghazadeh S, Yazdanparast R. Effects of Teucrium polium on insulin resistance in nonalcoholic steatohepatitis. J Acupunc Merid Stud. 3: 104-110, 2010.

Okita M, Hayashi M, Sasagawa T, Takagi K, Suzuki K, Kinoyama S, Ito T, Yamada G. Effect of a moderately energy-restricted diet on obese patients with fatty liver. Nutrition. 17: 542-547, 2001.

Oliveira CP, Gayotto LC, Tatai C, Della Nina BI, Lima ES, Abdalla DS, Lopasso FP, Laurindo FR, Carrilho FJ. Vitamin $\mathrm{C}$ and vitamin $\mathrm{E}$ in prevention of nonalcoholic fatty liver disease (NAFLD) in choline deficient diet fed rats. Nutr J. 7: 2-9, 2003.

Omagari K, Kato S, Tsuneyama K, Hatta H, Sato M, Hamasaki M, Sadakane Y, Tashiro T, Fukuhata M, Miyata Y, Tamaru S, Tanaka K, Mune M. Olive leaf extract prevents spontaneous occurrence of non-alcoholic steatohepatitis in SHR/NDmcr-cp rats. Pathology. 42: 66-72, 2010.

Osterreicher $\mathrm{CH}$, Brenner DA. The genetics of nonalcoholic fatty liver disease. Ann Hepatol. 6: 83-88, 2007.

Oz HS, Chen TS, Neuman M. Methionine deficiency and hepatic injury in a dietary steatohepatitis model. Dig Dis Sci. 53: 767-776, 2008.

Park HJ, DiNatale DA, Chung MY, Park YK, Lee JY, Koo SI, O'Connor M. Green tea extract attenuates hepatic steatosis by decreasing adipose lipogenesis and enhancing hepatic antioxidant defenses in $o b / o b$ mice. J Nutr Biochem. 22: 393-400, 2011.

Park SH, Lee SG, Kang SK, Chung SH. Acanthopanax senticosus reverses fatty liver disease and hyperglycemia in $o b / o b$ mice. Arch Pharm Res. 29: 768-776, 2006.

Patel T, Lee JG. Fatty liver. eMed J. 2: 8, 2001.

Pessayre D, Fromenty B, Mansouri A. Mitochondrial injury in steatohepatitis. Eur J Gastroenterol Hepatol. 16: 1095-1105, 2004.
Petta S, Muratore C, Craxi A. Non-alcoholic fatty liver disease pathogenesis: The present and the future. Dig Liver Dis. 41: 615-625, 2009.

Pradhan SC, Girish C. Hepatoprotective herbal drug, silymarin from experimental pharmacology to clinical medicine. Indian J Med Res. 124: 491-504, 2006.

Raju J, Bird RP. Alleviation of hepatic steatosis accompanied by modulation of plasma and liver TNF- $\alpha$ levels by Trigonella foenum graecum (fenugreek) seeds in Zucker obese ( $f a / f a$ ) rats. Int J Obes. 30: 1298-1307, 2006.

Ramalho RM, Cortez-Pinto H, Castro RE, Solá S, Costa A, Moura MC, Camilo ME, Rodrigues CM. Apoptosis and $\mathrm{Bcl}-2$ expression in the livers of patients with steatohepatitis. Eur J Gastroenterol Hepatol. 18: 21-29, 2006.

Rates SMK. Plants as source of drugs. Toxicon. 39: 603-613, 2001.

Ratziu V, Charlotte F, Heurtier A, Gombert S, Giral P, Bruckert E, Grimaldi A, Capron F, Poynard T; LIDO Study Group. Sampling variability of liver biopsy in nonalcoholic fatty liver disease. Gastroenterology. 128: 1898-1906, 2005.

Rinella ME, Elias MS, Smolak RR, Fu T, Borensztajn J, Green RM. Mechanisms of hepatic steatosis in mice fed a lipogenic methionine choline-deficient diet. J Lipid Res. 49: 1068-1076, 2008.

Romeo SJ. Kozlitina C, Xing A, Pertsemlidis D, Cox LA, Pennacchio E, Boerwinkle J, Cohen C, Hobbs $\mathrm{HH}$. Genetic variation in PNPLA3 confers susceptibility to nonalcoholic fatty liver disease. Nat Genet. 40: 1461-1465, 2000.

Roskams T, Yang SQ, Koteish A, Durnez A, DeVos R, Huang X, Achten R, Verslype C, Diehl, AM. Oxidative stress and oval cell accumulation in mice and humans with alcoholic and nonalcoholic fatty liver disease. Am J Pathol. 163: 1301-1311, 2003.

Sahoo N, Manchikanti P, Dey S. Herbal drugs: standards and regulation. Fitoterapia. 81: 462-471, 2010.

Sanyal AJ, Chalasani N, Kowdley KV, McCullough A, Diehl AM, Bass NM, Neuschwander-Tetri BA, Lavine JE, Tonascia J, Unalp A, Van Natta M, Clark J et al. Pioglitazone, vitamin E, or placebo for nonalcoholic steatohepatitis. N Engl J Med. 362: 1675-1685. 2010.

Sartorio A, Del Col A, Agosti F, Mazzilli G, Bellentani S, Tiribelli C, Bedogni G. Predictors of non-alcoholic fatty liver disease in obese children. Eur J Clin Nutr. 61: 877-883, 2007.

Shen B, Yu J, Wang S, Chu ES, Wong VW, Zhou X, Lin G, Sung JJ, Chan HL. Phyllanthus urinaria ameliorates the severity of nutritional 
steatohepatitis both in vitro and in vivo. Hepatology. 47: 473-483, 2008.

Shetty SN, Mengi S, Vaidya R, Vaidya AD. A study of standardized extracts of Picrorhiza kurroa Royle ex Benth. in experimental nonalcoholic fatty liver disease. J Ayurveda Integr Med. 1: 203-210, 2010.

Shiota G, Tsuchiya. Pathphysiology of NASH: Insulin resistance, free fatty acids and oxidative stress. J Clin Biochem Nutr. 38: 127-132, 2006.

Stefano JT, de Oliveira CP, Corrêa-Giannella ML, de Lima VM, de Sá SV, de Oliveira EP, de Mello ES, Giannella-Neto D, Alves VA, Carrilho FJ. Nonalcoholic steatohepatitis (NASH) in $o b / o b$ mice treated with yo jyo hen shi ko (YHK): effects on peroxisome proliferator-activated receptors (PPARs) and microsomal triglyceride transfer protein (MTP). Dig Dis Sci. 52: 3448-3454, 2007.

Stepanova M, Elariny H, Rafiq N, Afendy A, Srishord M, Younossi ZM, Baranova A, Srishord $\mathrm{M}$, Chandhoke V. Differences in hepatic gene expression of Caucasians and African American patients with non-alcoholic fatty liver disease (NAFLD)The $59^{\text {th }}$ Annual Meeting of the American Association for the Study of Liver Diseases. San Francisco, 2008.

Strauss RS, Barlow SE, Dietz WH. Prevalence of abnormal serum amino transferase values in overweight and obese adolescents. J Pediatr. 136: 727-733, 2000.

Tahan V, Eren F, Avsar E, Yavuz D, Yuksel M, Emekli E, Imeryuz N, Celikel C, Uzun H, Haklar G, Tozun N. Rosiglitazone Attenuates liver inflammation in a rat model of nonalcoholic steatohepatitis. Dig Dis Sci. 52: 3465-3472, 2007.

Takayama F, Egashira T, Kawasaki H, Mankura M, Nakamoto K, Okada S, Mori A. A Novel animal model of nonalcoholic steatohepatitis (NASH): hypoxemia enhances the development of NASH. J Clin Biochem Nutr. 45: 335-340, 2009a.

Takayama F, Nakamoto K, Kawasaki H, Mankura M, Egashira T, Ueki K, Hasegawa A, Okada S, Mori A. Beneficial effects of Vitis coignetiae Pulliat leaves on nonalcoholic steatohepatitis in a rat model. Acta Med Okayama. 63: 105-111, 2009b.

Targher G, Bertolini L, Rodella S, Zoppini G, Scala L, Zenari L, Falezza G. Associations between plasma adiponectin concentrations and liver histology in patients with nonalcoholic fatty liver disease. Clin Endocrinol. 64: 679-683, 2006.

Thounaojam M, Jadeja R, Ansarullah, Devkar R, Ramachandran AV. Dysregulation of lipid and cholesterol metabolism in high fat diet fed hyperlipidemic rats: Protective effect of Sida rhomboidea Roxb. leaf extract. J Health Sci. 55: 413-420, 2009.

Thounaojam MC, Jadeja RN, Ansarullah, Devkar RV, Ramachandran AV. Prevention of high fat diet induced insulin resistance in C57/BL/6J mice by Sida rhomboidea Roxb. extract. J Health Sci. 56: 92-98, 2010a.

Thounaojam MC, Jadeja RN, Patel DK, Devkar RV, Ramchandran AV. Acute and sub chronic oral toxicity of Sida rhomboidea Roxb. leaf extract. J Complement Integ Med. 7: 1, 2010 b.

Thounaojam MC, Jadeja RN, Devkar RV, Ramachandran AV. Sida rhomboidea Roxb. extract alleviates pathophysiological changes in experimental in vivo and in vitro models of high fat diet/fatty acid induced non-alcoholic steatohepatitis. Exp Toxicol Pathol. In press, 2010c.

Thounaojam MC, Jadeja RN, Ramani UV, Devkar RV, Ramachandran AV. Sida rhomboidea Roxb. leaf extract down-regulates expression of $P P A R \gamma 2$ and leptin genes in high fat diet fed C57BL/6J mice and retards in vitro 3T3L1 pre-adipocyte differentiation. Int J Mol Sci. 12: 4661-4677, 2011a.

Thounaojam MC, Jadeja RN, Devkar RV, Ramachandran AV. In Vitro evidence for the protective role of Sida rhomboidea Roxb. extract against LDL oxidation and oxidized LDL induced apoptosis in human monocyte derived macrophages. Cardiovasc Toxicol. 11: 168-179, 2011 b.

Tilg H, Moschen AR. Evolution of inflammation in nonalcoholic fatty liver disease: the multiple parallel hits hypothesis. Hepatology. 52: 1836-1846, 2010.

Vajro P, Mandato C, Franzese A, Ciccimarra E, Lucariello S, Savoia M, Capuano G, Migliaro F. Vitamin $\mathrm{E}$ treatment in pediatric obesity-related liver disease: a randomized study. J Pediatr Gastroenterol Nutr. 38: 48-55, 2004.

Valenti L, Al-Serri A, Daly AK, Galmozzi E, Rametta R, Dongiovanni P, Nobili V, Mozzi E, Roviaro G, Vanni E, Bugianesi E, Maggioni M et al. Homozygosity for the patatin-like phospholipase-3/adiponutrin I148M polymorphism influences liver fibrosis in patients with nonalcoholic fatty liver disease. Hepatology. 51: 1209-1217, 2010.

Velayudham A, Dolganiuc A, Ellis M, Petrasek J, Kodys K, Mandrekar P, Szabo G.VSL\#3 probiotic treatment attenuates fibrosis without changes in steatohepatitis in a diet-induced nonalcoholic steatohepatitis model in mice. Hepatology. 49: 989-997, 2009. 
Vendemiale G, Grattagliano I, Caraceni P, Caraccio G, Domenicali M, Dall'Agata M, Trevisani F, Guerrieri F, Bernardi M, Altomare E. Mitochondrial oxidative injury and energy metabolism alteration in rat fatty liver: effect of the nutritional status. Hepatology. 33: 808-815, 2001.

Wang GL, Fu YC, Xu WC, Feng YQ, Fang SR, Zhou $\mathrm{XH}$. Resveratrol inhibits the expression of SREBP1 in cell model of steatosis via Sirt1-FOXO1 signaling pathway. Biochem Biophys Res Commun. 380: 644-649, 2009.

WHO 1996. Guidelines for the Assessment of Herbal Medicines. WHO Expert Committee on Specification for Pharmaceutical Preparations. Technical Report Series No. 863. Geneva.

WHO. Guidelines for the Regulation of Herbal Medicines in the South-East Asia Region: Developed at the Regional Workshop on the Regulation of Herbal Medicines, Bangkok, and 24-26 June 2003. New Delhi: Regional office for South East Asia, World Health Organization; 2003.

WHO. Traditional medicine; 2008. http://www. who.int/mediacentre/factsheets/fs 134/en/ (accessed on 22 ${ }^{\text {nd }}$ March 2011).

Wilfred de Alwis NM, Day CP. Genetics of alcoholic liver disease and nonalcoholic fatty liver disease. Semin Liver Dis. 27: 44-54, 2007.

Willner IR, Waters B, Patil SR, Reuben A, Morelli J, Riely CA. Ninety patients with nonalcoholic steatohepatitis: insulin resistance, familial tendency and severity of disease. Am J Gastroenterol. 96: 2957-2961, 2001.

Xu A, Wang Y, Keshaw H, Xu LY, Lam KS, Cooper GJ. The fat-derived hormone adiponectin alleviates alcoholic and nonalcoholic fatty liver diseases in mice. J Clin Invest. 112: 91-100, 2003.

$\mathrm{Xu} \mathrm{KZ,} \mathrm{Zhu} \mathrm{C,} \mathrm{Kim} \mathrm{MS,} \mathrm{Yamahara} \mathrm{J,} \mathrm{Li} \mathrm{Y.}$ Pomegranate flower ameliorates fatty liver in an animal model of type 2 diabetes and obesity. J Ethnopharmacol. 123: 280-287, 2009.

Xu ZI, Fan JG, Ding XD, Qiao L, Wang GL. Characterization of high-fat, diet-induced, non-alcoholic steatohepatitis with fibrosis in rats. Dig Dis Sci. 55: 931-940, 2010.

Yang SF, Tseng JK, Chang YY, Chen YC. Flaxseed oil attenuates nonalcoholic fatty liver of hyperlipidemic hamsters. J Agric Food Chem. 57: 5078-5083, 2009.

Yao HR, Liu J, Plumeri D, Cao YB, He T, Lin L, Li Y, Jiang YY, Li J, Shang J. Lipotoxicity in HepG2 cells triggered by free fatty acids. Am J Transl Res. 3: 284-291, 2011.

Yoneda M, Hotta K, Nozaki Y, Endo H, Uchiyama T, Mawatari H, Iida H, Kato S, Fujita K, Takahashi $\mathrm{H}$, Kirikoshi H, Kobayashi N et al. Association between angiotensin II type 1 receptor polymorphisms and the occurrence of nonalcoholic fatty liver disease. Liver Int. 29: 1078-1085, 2009.

Yoshioka S, Hamada A, Jobu K, Yokota J, Onogawa M, Kyotani S, Miyamura M, Saibara T, Onishi S, Nishioka Y. Effects of Eriobotrya japonica seed extract on oxidative stress in rats with non-alcoholic steatohepatitis. J Pharm Pharmacol. 62: 241-246, 2010.

Zhu L, Luo X, Jin Z. Effect of resveratrol on serum and liver lipid profile and antioxidant activity in hyperlipidemia rats. Asian Australas J Anim Sci. 21: 890-895, 2008. 